\title{
PENGEMBANGAN MEDIA PEMBELAJARAN INTERAKTIF BERBASIS ANDROID PADA POKOK BAHASAN BARISAN DAN DERET ARITMATIKA
}

\author{
Denta Prabowo ${ }^{1}$, Heni Pujiastuti ${ }^{2}$, Yani Setiani $^{3}$ \\ Jurusan Pendidikan Matematika, Universitas Sultan Ageng Tirtayasa, Serang ${ }^{1,2,3}$ \\ prabowodenta53@gmail.com
}

\begin{abstract}
Abstrak
Penelitian ini bertujuan untukuntuk menghasilkan suatu produk, yaitu media pembelajaran interaktif berbasis android dengan memanfaatkan MIT App Inventor yang bisa digunakan dalam proses belajar baris dan deret. Prosedur penelitian dan pengembangan ini mengadaptasi prosedur yang dilakukan oleh Borg \& Gall (1983:775) dengan melibatkan tujuh langkah utama yaitu: 1) analisis kebutuhan; 2) kemampuan peneliti sebagai pengembang; 3) produk yang dikembangkan; 4) konsep produk; 5) pengembangan produk; 6) uji ahli; 7) uji coba produk. Hasil penelitian menunjukkan bahawa media pembelajaran interaktif berbasis android pada materi barisan dan deret aritmatika telah berhasil dikembangkan dengan memenuhi kriteria kualitas aplikasi. Hal ini menunjukkan bahwa media pembelajaran interaktif berbasis android yang telah dikembangkan dapat diterima dan digunakan sebagai salah satu media pembelajaran dan sumber belajar mandiri yang dapat diakses dengan fleksibel. Kata Kunci:Media pembelajaran interaktif, android, baris dan deret.
\end{abstract}

\begin{abstract}
This study aims to produce a product, an android-based interactive learning medium, by utilizing the MIT App Inventor, which can use in row and series learning. This research and development procedure adapts the procedure carried out by Borg \& Gall involving seven main steps, namely: 1) needs analysis; 2) the ability of researchers as developers; 3) developed products; 4) product concept; 5) product development; 6) expert test; 7) product trial. The results showed that the android-based interactive learning media on arithmetic sequences and sequences had been successfully developed by meeting the application quality criteria. It indicates that the Androidbased interactive learning media that has developed can be accepted and used as one of the learning media and independent learning resources that can be accessed flexibly.
\end{abstract}

Keywords: interactive learning media, android, lines, and series.

\section{PENDAHULUAN}

Pendidikan sangat berperan dalam membekali manusia menyongsong masa depan yang penuh dengan tantangan dan perubahan. Melalui pendidikan, manusia dapat menjadi pribadi yang berkualitas dan mandiri sehingga mampu membangun dirinya dan masyarakat sekelilingnya, sehingga akan terbentuk masyarakat yang cerdas dan berpengetahuan tinggi, mampu bersaing pada tingkat regional bahkan internasional sehingga dapat membantu kemajuan negara. Berhasil atau tidaknya pendidikan tidak terlepas dari beberapa faktor yang saling mendukung satu sama lain. Hasbullah (Hasbullah, 1999) mengatakan bahwa pendidikan dapat berhasil dengan melihat beberapa faktor yakni (1) tujuan, (2) pendidik, (3) anak didik, (4) alat pendidikan, dan (5) lingkungan. 
Faktor alat pendidikan dalam hal ini bahan ajar menjadi salah satu penentu keberhasilan pendidikan suatu negara. Bahan ajar selalu menjadi hal yang menarik untuk dikembangkan, terutama oleh praktisi pendidikan. Segala bentuk bahan yang dapat digunakan untuk proses pembelajaran termasuk ke dalam bahan ajar. Alternatif bahan ajar yang sering digunakan adalah media pembelajaran. Media pembelajaran menurut Briggs et al (Briggs, Smithson, Addison, \& Atkinson, 1997), adalah buku, film, video, slide, dan atau alat fisik lainnya yang dapat digunakan untuk menyampaikan informasi. Sistem pembelajaran menggunakan media akan menjadikan pembelajaran lebih efisien, efektif, dan relevan. Hal ini diperkuat oleh hasil penelitian yang dilakukan oleh Oktavera(Oktavera, 2015) yang menunjukkan bahwa terdapat pengaruh yang signifikan dengan adanya penggunaan media pembelajaran terhadap prestasi belajar siswa. Oleh karena itu, media pembelajaran sangat penting pada proses pembelajaran.

Memasuki abad ke-21, Teknologi Informasi dan Komunikasi (TIK) semakin berkembang, bahkan berlangsung sangat pesat dan menyeluruh. TIK dengan perkembangannya telah memasuki dunia pendidikan(Bidarra \& Rusman, 2017). Dalam proses pembelajaran pada masa kini, penggunaan TIK sangat penting. Mengingat, tuntutan abad 21, membutuhkan SDM yang siap dan handal dalam menggunakan teknologi. Dalam beberapa dekade terakhir, kepemilikan perangkat mobile khususnya smartphone di Indonesia semakin meningkat. Hal tersebut didukung oleh Mobility Report yang dirilis Ericsson(Anonym, 2018) untuk kawasan Asia Tenggara dan Oceania tahun 2016 yang menunjukkan bahwa Indonesia memiliki jumlah pengguna smartphone tertinggi di kawasan Asia Tenggara dan Oceania dengan memberikan kontribusi pertumbuhan jumlah pengguna baru smartphone sebanyak 5 juta di tahun 2016. Disebutkan pula dalam laporan tersebut, penetrasi pengguna smartphone di Indonesia pada tahun 2015 sebanyak 38\% dan diperkirakan hingga tahun 2021 akan meningkat menjadi 98\%. Bentuk smartphone merupakan perangkat mobile yang sedang berkembang. Berdasarkan data dari Jose(Jose, 2015) menyebutkan bahwa Indonesia mencapai 55 juta pengguna smarthphone. Semakin merambahnya pengguna smartphone membuat mobile device ini menjadi candu termasuk dalam pembelajaran. Dengan adanya smartphone, pengunduhan berbagai macam aplikasi seperti games dan social media dapat dilakukan oleh siswa. Berdasarkan data dari Kompas sampai tahun 2017, android merupakan sistem operasi smartphone yang memiliki penjualan terbanyak di Indonesia dengan presentasi $60,86 \%$, kemudian diikuti oleh windows 21,54\%, unknown 7,4\%, iOS 3,4\%, Nokia 2,32\%, OS X 1,41\% (Septania, 2018).

Berdasarkan observasi yang akan dilakukan di salah satu SMA di kota Serang, hampir semua siswa menggunakan smartphone. Akan tetapi siswa masih jarang menggunakan smartphone tersebut sebagai alat pembelajaran karena masih sedikitnya aplikasi untuk pembelajaran khususnya matematika yang dapat diakses dan dimanfaatkan oleh siswa. Semakin merambahnya penggunaan perangkat smartphone di kalangan siswa membuka peluang besar bagi para pendidik, khususnya praktisi pendidikan dalam bidang matematika untuk mengembangkan pembelajaran berbasis android (smartphone). Pengembangan perangkat mobile tersebut sebagai salah satu upaya pengadaan bahan ajar tepat guna yang inovatif serta bermakna, sehingga pada akhirnya dapat meningkatkan mutu pendidikan. 
Terdapat beberapa penelitian yang telah mengembangkan media pembelajaran interaktif. Salah satunya penelitian yang dilakukan oleh Mahendra(Mahendra, 2010) adalah pengembangan media pembelajaran berbasis blog pada mata pelajaran TIK. Pengembangan tersebut terbukti kelayakannya dan dapat meningkatkan hasil dan prestasi belajar siswa. Kelemahan pada media pembelajaran interaktif berbasis blog adalah untuk mengaksesnya memerlukan koneksi internet. Oleh karena itu peneliti memilih mengembangkan sebuah aplikasi media pembelajar interaktif berbasis android dengan bantuan MIT App Inventor menggunakan format apk, sehingga media pembelajaran interaktif dapat diakses baik online maupun offline.

Dalam pembelajaran matematika, salah satu materi yang dapat disajikan dalam media pembelajaran interaktif adalah barisan dan deret aritmatika. Di dalam kehidupan sehari hari materi ini sangat penting terutama dalam bisnis dan ekonomi. Menggunakan barisan dan deret aritmatika, perhitungan dapat dilakukan dengan lebih terstruktur dan sistematis. Sehingga dalam pembelajaranya memerlukan pemahaman dan ketelitian siswa dalam mencoba dan belajar mandiri. Kenyataan ini membuktikan kebutuhan akan adanya media pembelajaran yang bisa membantu memudahkan pembelajaran pada materi matematika tersebut, Maka telah melakukan penelitian dengan judul "Pengembangan Media Pembelajaran Interaktif Berbasis Android Pada Pokok Bahasan Barisan dan Deret Aritmatika".

\section{BAHAN DAN METODE}

Rancangan penelitian pengembangan ini bertujuan untuk menghasilkan suatu produk, yaitu sebuah bahan ajar interaktif berbasis android dengan memanfaatkan MIT App Inventor yang bisa digunakan dalam proses belajar mengajar dikelas.Prosedur penelitian dan pengembangan ini mengikuti prosedur yang dilakukan oleh Borg \& Gall (1983:775) dengan melibatkan tujuh langkah utama yaitu: 1) analisis kebutuhan; 2) kemampuan peneliti sebagai pengembang; 3) produk yang dikembangkan; 4) konsep produk; 5) pengembangan produk; 6) uji ahli; 7) uji coba produk.Secara singkat prosedur penelitian ditunjukkan pada Gambar 1. 


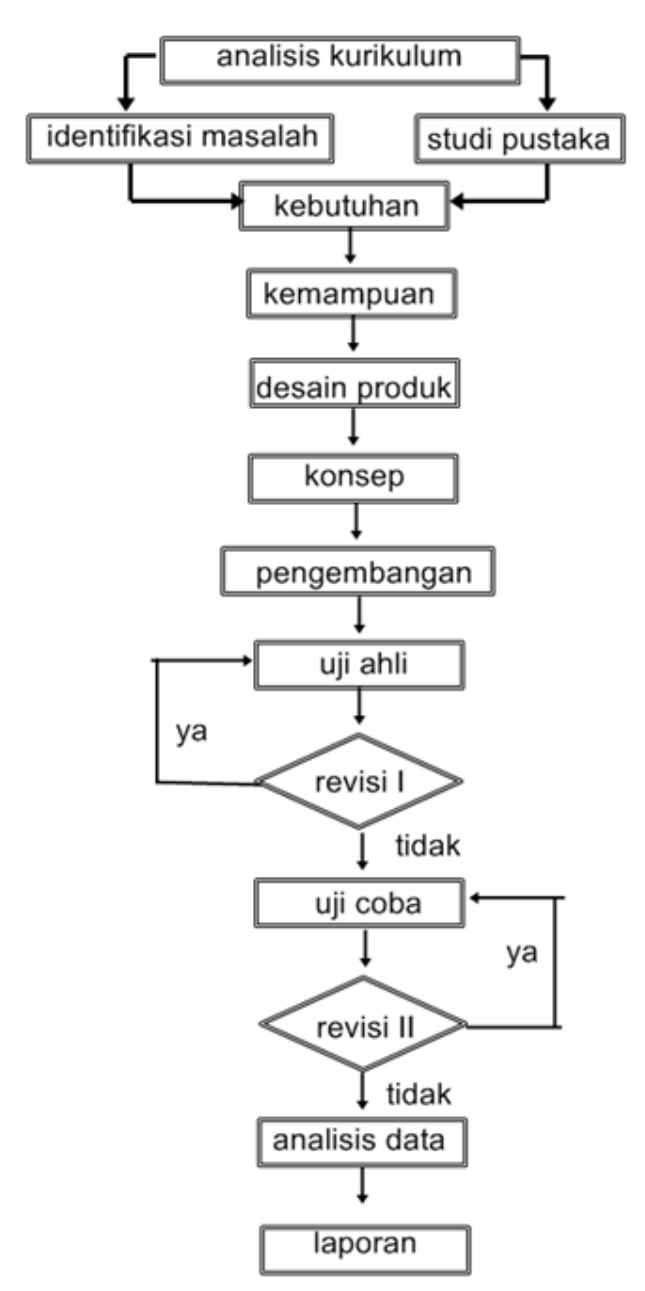

GAMBAR 1. Prosedur pengembangan media interaktif

Pada penelitian ini melibatkan 9 orang validator (expert judgement) dengan rincian 3 validator berkaitan dengan aspek pendidikan, 3 orang berkaitan dengan aspek materi matematika dan 3 orang berkaitan dengan aspek teknologi. Tahap validasi ini bertujuan untuk mengetahui apakah media pembelajaran interaktif berbasis android tersebut layak atau tidak untuk diuji cobakan. Uji coba produk dilakukan pada siswa SMA. Borg dan Gall (Sukmadinata \& Syaodih, 2006) menyatakan bahwa dalam uji coba terbatas dilakukan dengan menggunakan 6 sampai 12 subyek. Namun, dalam uji coba media pembelajaran interaktif berbasis android ini dilakukan kepada 20 siswa yang dianggap memiliki karakteristik yang sama dengan pengguna utama (main user). Pengguna utama merupakan siswa yang akan menggunakan media pembelajaran interaktif berbasis android. Adapun siswa dengan karakteristik yang sama dalam hal ini adalah siswa SMA yang telah diajarkan materi barisan dan deret aritmatika. Uji coba dilakukan untuk mengetahui penilaian siswa terhadap media pembelajaran interaktif berbasis android.

Instrumen yang digunakan berupa angket tertutup dan wawancara. Angket tertutup terdiri dari: a) Angket uji ahli teknologi,b) Angket uji ahli pendidikan,c) Angket uji ahli matematika,d) Angket uji coba. Indikator keberhasilan dalam penelitian ini adalah produk yang dikembangkan yaitu media pembelajaran interaktif berbasis android pada pokok bahasan barisan dan deret aritmatika 
terselesaikan dan valid. media pembelajaran interaktif dikatakan selesai apabila telah melalui tujuh langkah utama prosedur penelitian yang dilakukan pada penelitian dan pengembangan ini yaitu analisis kebutuhan, kemampuan peneliti sebagai pengembang, produk yang dikembangkan, konsep produk, pengembangan produk, uji ahli, dan uji coba produk. Selain menyelesaikan ketujuh tahap tersebut, pengembangan media pembelajaran interaktif interaktif berbasis android ini harus memenuhi kriteria penilaian kelayakan minimal yang dikatakan baik oleh Puslitjaknov (Puslitjaknov, 2008) yakni apabila penilaian telah mencapai 70\%.

\section{HASIL DAN PEMBAHASAN}

a. Hasil Analisis Kebutuhan

Hasil analisis permasalahan dasar yang ada di sekolah membuat pertimbangan bagi peneliti untuk mengembangkan media pembelajaran berupa aplikasi android yang bersifat fleksibel dan dapat membantu siswa dalam belajar mandiri. Hasil obeservasi di salah satu SMA di Kota Serang menunjukkan bahwa sebagian besar siswa cenderung agak malas dalam mempelajari materi baris dan deret aritmatika. Hal ini disebabkan karena materi mengandung angka yang banyak dan terkadang contoh soal yang diberikan terlalu sulit melibatkan angka ratusan sampai ribuan. Siswa yang lemah dalam penjumlahan mengalami kesulitan. Selain itu, penyampaian materi didominasi dengan metode ceramah, sehingga siswa enggan untuk belajar lebih jauh. Alternatif dalam pembelajaran ini adalah guru harus membuat penyampaian pembelajaran yang dapat divisualkan agar siswa dapat lebih mudah memahami materi tersebut. Oleh karenanya, peneliti memilih materi barisan dan deret aritmatika untuk dimuat dalam media yang dikembangkan. Berikut adalah tujuan pembelajaran dari hasil analisis kebutuhan pada materi barisan dan deret aritmatika: a) Menemukan konsep barisan aritmatika; b) Menemukan konsep deret aritmatika; c) Menentukan suku ke- $\mathrm{n}$ barisan aritmatika; d) Menghitung jumlah $\mathrm{n}$ suku pertama deret aritmatika.

\section{b. Hasil Tahap Pengembangan}

Setelah tahap analisis kebutuhan, kemampuan peneliti dan mendesain selesai dilakukan, maka tahap selanjutnya adalah tahap pengembangan. Tahap pengembangan media mengacu pada flowchart dan storyboard yang sudah disusun pada tahap perancangan (design).

Pengembangan Media Pembelajaran interaktif berbasis android pada pokok bahasan barisan dan deret aritmatika dikembangkan dengan menggunakan web design platform android yaitu MIT App Inventor, sedangkan untuk membuat design background serta bahan lainnya menggunakan Corel. Media Pembelajaran interaktif barisan dan deret aritmatika yang dikembangkan peneliti meliputi halaman awal, halaman menu, halaman goals, halaman materi, halaman evaluasi, halaman help dan halaman tentang penulis yang dapat dilihat pada GAMBAR 2 . 


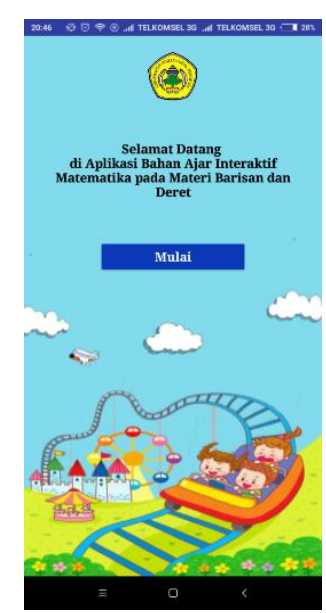

(a)

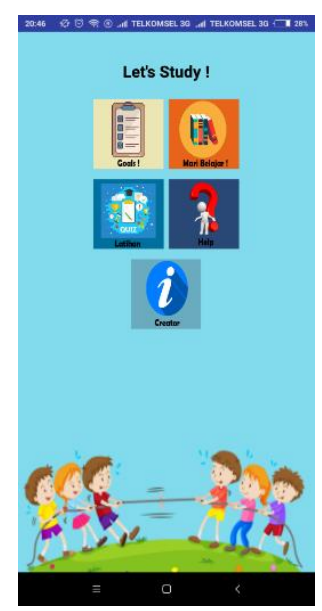

(b)

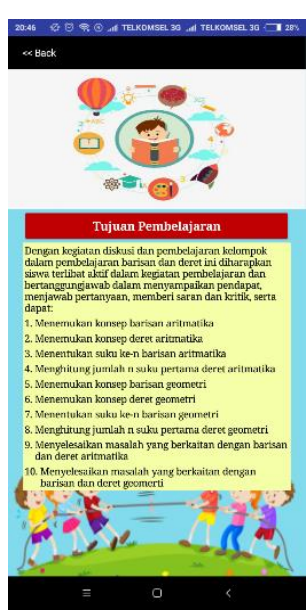

(c)

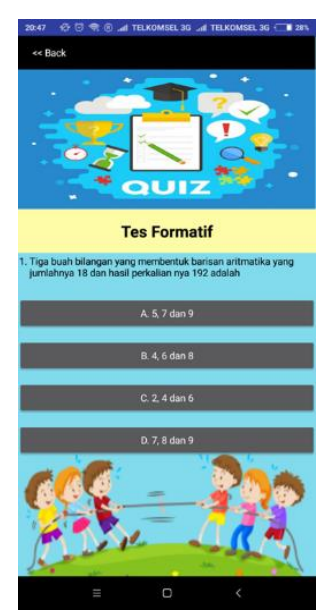

(d)

GAMBAR 2. (a) Cover depan/ halaman awal, (b) Halaman menu, (c) Halaman goals dan (d) halaman evaluasi.

1). Expert apprasial

Setelah pembuatan Media Pembelajaran interaktif kemudian dikonsultasikan untuk dinilai oleh3 ahli teknologi, 3 ahli pendidikan dan 3 ahli matematika. Tabel 1, 2 dan 3 menunjukkan hasil validasi dari beberapa ahli.

Tabel 1. Hasil validasi ahli teknologi

\begin{tabular}{ccccc}
\hline No & Aspek Penilaian & Hasil I (\%) & Hasil II (\%) & Hasil III (\%) \\
\hline 1 & Tampilan & 93 & 85 & 89 \\
\hline 2 & Keberfungsian & 93 & 84 & 89 \\
\hline \multicolumn{2}{c}{ Rata-rata } & 93 & 93 & 84,5 \\
\hline Rata-rata keseluruhan & \multicolumn{3}{c}{ Sangat Layak } \\
\hline \multicolumn{2}{c}{ Interpretasi }
\end{tabular}

Tabel 2. Hasil validasi ahli pendidikan

\begin{tabular}{|c|c|c|c|c|}
\hline No & Aspek Penilaian & Hasil I (\%) & Hasil II (\%) & Hasil III (\%) \\
\hline 1 & Relevansi materi & 93 & 90 & 87 \\
\hline 2 & Bahasa & 91 & 89 & 92 \\
\hline \multirow[t]{2}{*}{3} & Strategi pembelajaran & 91 & 88 & 90 \\
\hline & Rata-rata & 92 & 91,7 & 89,0 \\
\hline & Rata-rata keseluruhan & & 90,1 & \\
\hline & Interpretasi & & Sangat Layak & \\
\hline
\end{tabular}

Tabel 3. Hasil validasi ahli matematika

\begin{tabular}{ccccc}
\hline No & Aspek Penilaian & Hasil I (\%) & Hasil II (\%) & Hasil III (\%) \\
\hline 1 & Kualitas isi & 90 & 87 & 90 \\
\hline 2 & Penyajian materi & 89 & 89 & 91 \\
\hline 3 & Kebahasaan & 92 & 90 & 90 \\
\hline & Rata-rata & 90 & 90,3 & 88,7 \\
\hline
\end{tabular}




\begin{tabular}{cc}
\hline Rata-rata keseluruhan & 89,8 \\
\hline Interpretasi & Sangat Layak \\
\hline
\end{tabular}

Tabel 1-3 menyatakan bahwa hasil validasi oleh ahli terhadap Media Pembelajaran matematika interaktif pada materi barisan dan deret aritmatika secara keseluruhan memperoleh kategori sangat layak

\section{2). Developmental testing}

Setelah melakukan perbaikan berdasarkan masukkan dan saran dari tim ahli (ahli media, ahli materi dan ahli pendidikan), selanjutnya dilakukan uji coba terbatas kepada siswa/i SMA Prisma Kota Serang sebanyak 20 siswa. Uji coba ini dilakukan untuk mengetahui respon siswa terhadap media dan materi yang telah dibuat dari aspek media dan materi. Hasil penilaian siswa dari uji coba terbatas terhadap Media Pembelajaran interaktif pada materi barisan dan deret aritmatika ditunjukkan pada Tabel 4.7.

Tabel 4. Rerata hasil uji coba terbatas Media Pembelajaran interkatif materi barisan dan deret aritmatika

\begin{tabular}{cccc}
\hline No & Aspek Penilaian & Hasil \% & Kategori \\
\hline 1 & Kualitas komunikasi visual & 80 & Baik \\
\hline 2 & Kualitas teknis & 83 & Sangat baik \\
\hline 3 & Kualitas instruksional & 84 & Sangat baik \\
\hline & Rata-rata & 82,3 & Sangat baik \\
\hline
\end{tabular}

Tabel 4 menyatakan bahwa hasil uji coba terbatas Media Pembelajaran interaktif pada materi barisan dan deret aritmatika secara keseluruhan memperoleh nilai sebesar $82,3 \%$ dengan kategori sangat baik

\section{c. Pembahasan}

Desain Media Pembelajaran interaktif matematika pada materi barisan dan deret aritmatika yang telah divalidasi dan direvisi berdasarkan saran dari para ahli berisikan 7 komponen utama, yaitu tampilan awal; tampilan utama atau menu; tampilan Goals yang berisi tujuan pembelajran; tampilan materi yang berisi subbab barisan dan deret aritmatika; tampilan latihan; tampilan help atau bantuan; dan tampilan creator atau penulis.Media Pembelajaran interkatif matematika pada materi barisan dan deret aritmatika yang dikembangkan telah dinilai oleh tim ahli (ahli teknologi, ahli pendidikan dan ahli materi matematika. Berdasarkan hasil penilaian oleh ahli teknologi didapatkan rata-rata hasil sebesar $88,8 \%$ dengan kategori sangat layak, begitu pula hasil dari validasi ahli pendidikan didapatkan rata-rata hasil sebesar $90,1 \%$ dengan kategori sangat layak setelah melakukan beberapa revisi. Sedangkan dari ahli materi diperoleh nilai sebesar 89,8\% dengan kategori sangat layak. Setelah melakukan revisi oleh ahli teknologi, pendidikan dan materi dilakukan uji coba terbatas pada 20 peserta didik SMA Prisma Kota Serang dan di dapatkan hasil uji coba terbatas sebesar 82,3\% dengan kategori sangat baik. Berdasarkan uraian di atas, maka dapat disintesiskan bahwa uji kelayakan oleh ahli teknologi memperoleh persentase rata-rata sebesar 88,8\% dengan kategori sangat layak. Sedangkan menurut perolehan dari ahli pendidikan dapat dijelaskan melalui beberapa aspek, yaitu aspek relevansi materi dengan perolehan skor 90\%, aspek 
bahasa sebesar 90,6\% dan aspek strategi pembelajaran sebesar 89,6\%. Berdasarkan uraian diatas, maka dapat disintesiskan bahwa uji kelayakan oleh ahli pendidikan memperoleh persentase rata-rata sebesar 90,1\% dengan kategori sangat layak. Menurut penilaian ahli materi melaluibeberapa aspek, yaitu aspek kualitas isi dengan perolehan skor $89 \%$, aspek penyajian materi sebesar $89,7 \%$ dan aspek kebahasaan sebesar 90,7\%. Berdasarkan uraian diatas, maka dapat disintesiskan bahwa uji kelayakan oleh ahli materi memperoleh persentase rata-rata sebesar $89,8 \%$ dengan kategori sangat layak. Sedangkan hasil uji coba terbatas oleh peserta didik melalui beberapa aspek, yaitu aspek komunikasi visual sebesar 80\%, aspek teknis sebesar $83 \%$ dan aspek instruksional sebesar $84 \%$. Berdasarkan uraian diatas, maka dapat disintesiskan bahwa uji coba terbatas oleh peserta didik memperoleh persentase rata-rata sebesar $82,3 \%$ dengan kategori sangat layak.

Berdasarkan uraian penjelasan sebelumnya, dapat disintesiskan bahwa Media Pembelajaran interaktif matematika dikatakan layak digunakan dengan keunggulan dan kekurangan dibawah ini: a) Keunggulan. Media Pembelajaran interaktif matematika dapat digunakan sebagai alternatif media pembelajaran yang fleksibel dan dapat diakses dengan mudah. Selain itu dalam Media Pembelajaran ini disertai gambar untuk mempermudah memahami materi. Serta terdapat latihan soal untuk mengevaluasi hasil belajar. Dalam penyajiannya Media Pembelajaran disesuaikan dengan kebutuhan siswadan dibuat sedemikian rupa sehingga dapat menarik minat belajar peserta didik(Irsyad, 2016). b) Kekurangan. Keterbatasan peneliti dalam memahami block dan komponen dalam pembuatan media pada platform web (MIT App Inventor dan Kodular) menjadi hambatan bagi peneliti dalam mengeksplor seluruh komponen yang terdapat didalamnya, sehingga tidak dapat membuat lebih dari yang diharapkan. Misalnya, dalam Media Pembelajaran tidak terdapat video maupun animasi.

\section{KESIMPULAN}

Berdasarkan hasil dari penelitian ini, penulis dapat mengambil beberapa kesimpulan, yaitu: a) Dari hasil pengembangan dihasilkan media pembelajaran yang memiliki tujuh komponen utama. Tujuh komponen tersebut yaitu halaman intro (Screen1), menu utama (Home), goals (berisi tujuan pembelajaran), mari belajar (berisi materi), latihan, help dan creator. b) Media pembelajaran interaktif berbasis android pada materi barisan dan deret aritmatika telah berhasil dikembangkan dengan memenuhi kriteria kualitas aplikasi. Hal ini menunjukkan bahwa media pembelajaran interaktif berbasis android yang telah dikembangkan dapat diterima dan digunakan sebagai salah satu media pembelajaran dan sumber belajar mandiri yang dapat diakses dengan fleksibel.

\section{DAFTAR RUJUKAN}

Anonym. (2018). Ericsson Mobility Report. Retrieved from https://www.ericsson.com/en/mobility-report/reports/november-2018

Bidarra, J., \& Rusman, E. (2017). Towards a pedagogical model for science education: bridging educational contexts through a blended learning approach. Open Learning, 32(1), 6-20. https://doi.org/10.1080/02680513.2016.1265442

Briggs, D., Smithson, P., Addison, K., \& Atkinson, K. (1997). Fundamentals of the physical environment second edition. Routledge, 29 West 35 Th Street, New York, NY 10001 2299(USA). 557, 557.

Hasbullah. (1999). Kapita Selekta Pendidikan Islam. Jakarta: Raja Grafindo.

Irsyad, H. (2016). Aplikasi Android dalam 5 Menit. Jakarta: Elex Media Komputindo. 
Jose, A. (2015). 2015, Pengguna Smartphone di Indonesia Capai 55 Juta. Retrieved from https://techno.okezone.com/read/2015/09/19/57/1217340/2015-pengguna-smartphone-diindonesia-capai-55-juta

Mahendra, I. G. J. (2010). Pengembangan Media Pembelajaran Berbasis Blog pada Mata Pelajaran Teknologi Informasi dan Komunikasi Kelas VII SMP Negeri 1 Sukasada. Jurnal Pendidikan.

Oktavera, S. (2015). Pengaruh Media Pembelajaran dan Kemandirian Belajar terhadap Hasil Belajar IPA Siswa Kelas IV Sekolah Dasar. Jurnal Pendidikan Dasar, 6(2), 328.

Puslitjaknov. (2008). Metodologi Penelitian Pengembangan.

Septania, R. C. (2018). Berapa Populasi OS Android pada Akhir 2017? Retrieved from https://tekno.kompas.com/read/2018/01/08/10364647/berapa-populasi-os-android-padaakhir-2017

Sukmadinata, \& Syaodih, N. (2006). Metode Penelitian Pendidikan. Bandung: Remaja Rosdakarya. 